\title{
ANNE SCHOYSMAN, “Mimésis”, X: les variantes du réalisme "créaturel"
}

\section{Maria Colombo Timelli}

\section{OpenEdition}

\section{Journals}

\section{Édition électronique}

URL : https://journals.openedition.org/studifrancesi/45714

DOI : $10.4000 /$ studifrancesi.45714

ISSN : 2421-5856

\section{Éditeur}

Rosenberg \& Sellier

\section{Édition imprimée}

Date de publication : 1 novembre 2010

Pagination : 534

ISSN : 0039-2944

\section{Référence électronique}

Maria Colombo Timelli, " anne schoysman, "Mimésis", X: les variantes du réalisme "créaturel” », Studi Francesi [En ligne], 162 (LIV | III) | 2010, mis en ligne le 01 novembre 2010, consulté le 11 novembre 2021. URL : http://journals.openedition.org/studifrancesi/45714 ; DOI : https://doi.org/10.4000/ studifrancesi. 45714

Ce document a été généré automatiquement le 11 novembre 2021.

\section{(c) (i) (9) $\Theta$}

Studi Francesi è distribuita con Licenza Creative Commons Attribuzione - Non commerciale - Non opere derivate 4.0 Internazionale. 


\title{
ANNE SCHOYSMAN, “Mimésis", X: les variantes du réalisme "créaturel"
}

\author{
Maria Colombo Timelli
}

\section{RÉFÉRENCE}

ANNE SCHOYSMAN, "Mimésis", X: les variantes du réalisme "créaturel”, dans «Moderna», XI,

1-2, 2009, Erich Auerbach, a cura di Mario DOMENICHELLI e Maria Luisa MENEGHETTI,

pp. 153-164.

1 Après avoir resitué le chapitre consacré au Reconfort de Madame de Fresne d'Antoine de La Sale dans le plan d'ensemble de Mimésis, A.S. rappelle le double jugement d'Auerbach - un jugement fortement négatif sur le plan de la langue, positif sur le contraste établi entre le réalisme du quotidien et le tragique qui s'y mêle - sur une œuvre qui demeure aujourd'hui encore peu connue. L'adjectif «créaturel» (le néologisme est introduit par le critique allemand dans ce même chapitre X) définit le réalisme bourguignon de la fin du Moyen Âge, un réalisme encore "étroit et médiéval» si on le compare à celui d'un Dante ou d'un Boccace, mais un réalisme qui introduit et approfondit pour la première fois dans la littérature française la dimension du tragique de la vie. 